\title{
Percepções e Aproximações do Documento na Historiografia, Documentação e Ciência da Informação ${ }^{1}$
}

\author{
Perceptions and Approaches of the document in the Historiography, Documentation and \\ Information Science
}

Eduardo Ismael Murguia

Pós-doutor em Ciência da Informação pelo IBICT

Docente dos Programas de Pós-Graduação em Ciência da Informação da UFF e UNESP/Marília

E-mail: murguia@vm.uff.br

\begin{abstract}
Resumo
O presente trabalho pretende contribuir ao debate sobre a elaboração de um corpus teórico que interprete o documento. O ensaio bibliográfico que apresentamos, aspira a sistematizar e conduzir uma discussão sobre o documento sob algumas das óticas desde a qual foi interpretado. A revisão contempla a Historiografia, a Documentação, a Arquivologia, para depois identificar as maneiras pelas quais a Ciência da informação se vincula com essas outras áreas.
\end{abstract}

Palavras-chave: Documento; Ciência da Informação

\begin{abstract}
The present work aims to contribute to the discussion on developing a theoretical body in order to interpret the document. This paper is typified as a bibliographic essay that aspires to organize and lead that discussion on the document, provided of some optics under which it was interpreted. The review includes Historiography, Documentation, Archival Science, and it tries to identify the ways Information Science is linked with these other areas.
\end{abstract}

Keywords: Document; Information Science

O ponto principal para o tratamento da relação entre informação, documento e História será estabelecido com base no estágio da informação denominado por Buckland (1991) como informação-como-coisa, ou seja, a informação materializada. Isso porque nossa intenção é enfatizar a construção da informação materializada em documentos institucionais e os estratos burocráticos $^{2}$ que influenciam e determinam, por meio de relações e jogos de poder, a construção de documentos, de emergências e de definições sociais e culturais na esfera patrimonial. Nessa proposta, iniciaremos a abordagem da relação entre informação, documento e História pelo viés da Historiografia e da Documentação.

\footnotetext{
${ }^{1}$ Texto apresentado ao Instituto Brasileiro de Informação em Ciência e Tecnologia (IBICT), como parte dos requisitos do estagio de pós-doutorado, realizado de outubro de 2009 a abril de 2010.

$2 \mathrm{O}$ termo estratos burocráticos é utilizado neste trabalho como referência às instâncias administrativas institucionais que podem ser analisadas hierarquicamente ou por meio das diversas relações e inter-relações que assumem no decorrer do exercício de suas práticas. Assim, a partir das colocações de Foucault (1979, p. 75), esse termo será aplicado a um campo específico de funcionamento e exercício do poder, como um recurso para analisar como, onde e quem pratica o poder; como estes estratos se desenvolvem em focos particulares de poder.
}

InCID: R. Ci. Inf. e Doc., Ribeirão Preto, v. 2, n. 2, p. 42-53, jul./dez. 2011. 
No campo da Historiografia, Le Goff (2003, p. 535-536) mostra que o documento não é neutro nem inócuo, mas um conjunto de escolhas, resultado de uma montagem (consciente ou inconsciente), a representação de determinações, o registro de evidências; são formulações objetivas e subjetivas dentro do seu universo de produção, pois servem como instrumentos eficazes para atender a necessidade de perpetuar decisões, opiniões e acontecimentos. Assim, não deve ficar por conta do passado, pois é a representação do universo intelectual dos seus produtores e retrata a intenção do registro de um conhecimento específico, é um produto da sociedade que o fabricou, segundo as relações de força que aí detinham o poder.

Vemos frequentemente, no percurso da Historiografia, o termo documento utilizado para designar testemunho histórico e podemos supor que essa questão acompanhou o fazer histórico desde os seus primórdios. No entanto, esta ideia partilha dos preceitos da escola positivista, com raízes nos séculos XIX e XX. Neste sentido, tanto os historiadores, como os arquivistas embasados em visões positivistas, utilizaram o documento como provas de uma ação, afastando qualquer subjetividade e intencionalidade que pudesse opor-se a objetividade da produção documental. No século XX, principalmente, o documento tornou-se recurso necessário e indispensável para os pesquisadores que tinham por obrigação apresentar as suas fontes de informações como recurso para garantir confiabilidade aos trabalhos por eles produzidos.

Segundo a visão positivista da História, não há história sem documentos, principalmente os escritos. No entanto, Fustel de Coulanges propôs outro ponto de vista sobre a questão dizendo que: se faltar à História monumentos escritos, esta deverá atentar-se às fábulas, aos mitos, aos sonhos da imaginação; às marcar deixadas pelo homem por onde passou, aos elementos que representem toda a inteligência humana; nesses é que reside a história (apud Le Goff, 2003, p. 530).

Todavia, a utilização de fontes não escritas - visuais, sonoras, materiais e imateriais só foram aceitas através das propostas da Escola dos Annales. Segundo Lefebvre, representante desta Escola Historiográfica, a história é feita com documentos escritos, mas também pode fazer-se de outras maneiras: com palavras, signos, paisagens. "Numa palavra, com tudo o que, pertencendo ao homem, depende do homem, serve o homem, exprime o homem, demonstra a presença, a atividade, os gostos e as maneiras de ser do homem" (apud Le Goff, 2003, p. 530).

Para Lefebvre, a parte mais apaixonante do trabalho dos historiadores é fazer falar as coisas mudas, é descobrir o que elas não disseram sobre os homens e mais tentar suprir a 
ausência do documento escrito. Nessa nova perspectiva historiográfica, a noção de documento foi ampliada.

No entanto, as propostas desta nova escola não aconteceram por acaso, estiveram atreladas aos novos meios de produção e reprodução documental. Ou seja, através do desenvolvimento de novos recursos para uso da produção e reprodução de documentos, houve também aumento da vontade de registrar momentos da vida particular e acontecimentos do mundo ao nosso redor. Assim, os caminhos da Historiografia e da Documentação cruzaram-se e tornaram-se paralelos, isso quer dizer, coexistiram e não podemos afirmar que um veio antes do outro.

Os diferentes suportes que apareceram após o surgimento das novas tecnologias, apresentaram outros caminhos para aquisição de informações. Nesse contexto, o desafio era conseguir trabalhar com informações registradas não só em documentos manuscritos, mas com imagens e inscrições em diferentes tipos de suportes.

Outra contribuição importante para a noção de documento foi apresentada por Paul Zumthor. Segundo o autor, o que transforma o documento em monumento é a sua utilização pelo poder. No entanto, Le Goff (2003, p. 535) diz que Zumthor hesitava em apresentar o fosso que consistia em reconhecer em todo o documento um monumento. Nessa perspectiva, apresentou um ponto fundamental que vai de encontro com a noção positivista de documento, dizendo que não existe documento objetivo, inócuo. Essa ilusão estava pautada no interesse de uma sociedade cujos dominantes pretendiam que assim fosse, os quais compreendiam o documento como prova de boa fé, autênticos; características difíceis de serem pensadas com a ampliação dos meios de produção documental.

A revolução documental, a revolução nos meios de produção e reprodução de documentos foram, aos poucos, incentivando o afastamento dos profissionais da História e das Ciências da Informação da ilusão positivista de que o documento é objetivo e inócuo. Mas adeptos da tradição positivista ainda contestam a intencionalidade e a subjetividade envoltas na produção de documentos. Essa pretensiosa noção de objetividade é o que impede que muitos trabalhos sejam formulados com o intuito de tratar a natureza social dos documentos e a importância destes como produtos construídos para atender necessidades de sociedades e momentos históricos específicos.

$\mathrm{Na}$ área da Documentação e da Ciência da Informação, a concepção clássica da noção de documento tem como principais representantes Paul Otlet e Suzanne Briet, com as respectivas obras: Traité de Documentation (1934) e Qu'est-ce que La documentation? (1951). Considerados autores pioneiros na história dessas duas áreas, trabalharam a noção de 
documento a partir de novas possibilidades, o que abriu precedentes para pensá-los como informação fixada em diferentes tipos de suporte e a partir do seu papel social.

Paul Otlet enxergou os documentos em todos os lugares como uma força profundamente social, como o centro de um complexo processo de comunicação, acumulação e transmissão de conhecimentos. Para ele, os volumes, folhetos, revistas, artigos, cartas, diagramas, fotografias, estampas, certificados, estatísticas, discos fotográficos e filmes cinematográficos representam esse complexo processo. Segundo o autor, as intensidades que dão poder a diversos fluxos de energias intelectuais (informações e documentos) são recolhidos e coordenados pela produção documental, instalando, assim, autoridade aos trabalhos das associações e instituições. Como Frohmann (2007) demonstra, Otlet trabalhava com o intuito de garantir a objetividade no curso da produção científica: para ele, se os autores seguissem uma ordem, um método seria possível afastar a contaminação dos sinais, pois esta não está nas coisas, mas em quem as opera.

Já Suzanne Briet tratou os documentos a partir de suas estruturas físicas e abstratas. Inicialmente, a autora, apresentou o documento como: conhecimento fixado materialmente para finalidade de consulta, estudo ou prova. Essa visão, entretanto, foi ampliada e Briet começou a conceber o documento a partir de ideias mais abstratas, mostrando-o como "indício concreto ou simbólico, conservado ou registrado com o fim de representar, reconstruir ou provar um fenômeno físico ou intelectual” (apud Bravo, 2002, p. 92).

Rayward (apud Frohmann, 2007, p. 75), apresenta a obra de Otlet, Traité de Documentation (1934), como uma das primeiras introduções compreensivas do estado de informação como fenômeno social importante. Apesar disso, Otlet ainda mantinha sua preocupação com o conhecimento objetivo. Uma visão autoritária do conhecimento, talvez reducionista, embasada na questão da necessidade de institucionalização de certos processos visando analisar e organizar o conteúdo dos documentos (Hjorland, 2000, p. 32-33, tradução nossa).

Embora no processo de produção documental, especialmente quando tratamos de documentos administrativos, exista uma escrita disciplinar, que é ordenada e segue regras institucionais, não podemos deixar de levar em conta as intencionalidades, individuais e coletivas, envoltas em toda a elaboração de documentos.

As funções e abrangências dos documentos podem ser diversas. Um documento pode ser produzido e utilizado para definir, controlar, executar e/ou instituir um ato. A sua produção pode ser a representação de entidades e pessoas que os elaboram ou os utilizam. Mas o fato é que, em qualquer circunstância, devemos considerar o universo de constituição 
dos documentos - os produtores e o contexto de produção (Couture, 1996). Verificamos, assim, que muitos documentos são preservados, principalmente em arquivos institucionais, não por seu valor histórico, de prova ou de consulta, mas porque têm um poder particular de decisão, que vincula a organização e os indivíduos em suas ações (Senécal, 1997-1998).

Por meio dessas diferentes visões, podemos analisar o documento a partir de suas estruturas físicas e abstratas e, também, através de alguns de seus componentes: informação e suporte - embora muitos autores ainda carreguem a idéia da objetividade na produção de documentos passaram e levar também em consideração a informação registrada em diferentes tipos de suportes.

No âmbito da Diplomática ${ }^{3}$, algumas considerações de Tallafigo (2007) sobre os elementos extrínsecos e intrínsecos ${ }^{4}$ do documento são de nosso interesse para verificarmos de que maneira tais itens auxiliam na identificação e valorização do mesmo. Para este autor, as propriedades extrínsecas de um documento fariam referência aos elementos externos, sua forma, os materiais de sua composição. Já as intrínsecas, à formulação do discurso e conteúdo do documento, em seu teor, articulação e compostura das palavras. Portanto, para este autor, a idéia de documento refere-se ao suporte e ao seu conteúdo.

Já Bellotto (1991) trata a concepção de documento a partir da sua construção/proveniência. Para a autora, a forma/função pela qual um documento é criado é o que vai determinar seu uso, é a razão de sua origem e emprego, e não o suporte sobre o qual está constituído, o que vai determinar sua condição de documento. Os documentos administrativos ou jurídicos servem, portanto, como prova de uma ação e podem, em um segundo momento, serem utilizados para fins históricos. Eles surgem, pois, para atender às funções administrativas e legais e servem para provar ou testemunhar algo.

Senécal (1997-1998) diz que um documento considerado administrativo tem a função de definir, controlar, executar ou aconselhar sobre processos de trabalho, atividades ou itens para levar a cabo as atividades de uma organização. Para Senécal, o mesmo objeto pode ser reconhecido como um documento de arquivo se for possível perceber as características que confirmam as funções para representar a pessoa ou entidade utilizadora desses documentos.

Couture (1996) apresenta várias maneiras de definir um documento, por exemplo, como um recipiente de informações. Ao citar a Lei de Arquivos do Canadá (1987), diz que os documentos são "todos os elementos de informação, independente de sua forma e suporte,

\footnotetext{
${ }^{3}$ Como apresenta Bellotto (1991, p. 30), "dentro das ciências documentárias a diplomática é a atividade que se ocupa da descrição e da explicação dos atos escritos; seu campo de aplicação são os documentos gerados na área pública, neles estabelecendo as formas que lhe conferirão validade legal".

${ }^{4}$ Marc Block tratou sobre esta questão na obra Apologia da história ou o ofício de historiador (2002).
} 
incluindo correspondência, nota, livro, mapa, desenho, diagrama, ilustração gráfica, fotografia, cinema, microfilmes, gravação sonora, vídeo ou toda reprodução destes elementos". Segundo Couture (1996, p. 7), podemos definir o documento de arquivo como um recipiente/suporte para o conteúdo, opção que também foi escolhida pelo Conselho Internacional de Arquivos em 1984, o qual diz ser o documento: "informação gravada (documentos), independente da forma ou meio criado, recebido ou mantido por uma agência, instituição, organização ou indivíduo em cumprimento das obrigações legais ou na transmissão de negócios".

Por meio destas definições, Couture (1996) nos mostra a grande vantagem ao colocarmos a informação no mesmo patamar de igualdade do documento, pois desta forma é possível analisarmos o documento como meio de prova e consulta e, também, por meio do universo de sua constituição (produtor e contexto de produção).

Fuster Ruiz (1999) trata os documentos a partir de três fases, a saber: o documento como autoridade/testemunho, o documento como veracidade e o documento como autenticidade. Para ele, o documento é um objeto material, produto da atividade humana, que serve de fonte de conhecimento, que testemunha ou prova algo; é um testemunho da atividade humana fixado em um suporte perdurável que contém informação. Para melhor organização, o autor divide os documentos em duas classes: 1) documentos de natureza exclusivamente jurídica, os quais engendram direitos e obrigações; 2) documentos de natureza administrativa, que não tem natureza jurídica, mas que sem embargo são documentos testemunhais, autênticos, objetivos e, portanto, verídicos ou verdadeiros.

Outra colocação do autor que merece menção é a ideia de que o valor testemunhal e o informativo dos documentos são elementos diferentes. Para Fuster Ruiz (1999), os documentos são testemunhos e informação e podem ser utilizados como prova e como fonte de dados. No entanto, pontua que o valor testemunhal científico é algo distinto ao valor informativo. Nesse sentido, explica que todos os documentos dão notícia de algo, informam sobre algo, mas somente o documento de arquivo é verdadeiro, autêntico e imparcial. Em outras palavras, os documentos de arquivo não informam somente, mas dão garantia de que um feito relatado é verdadeiro e, portanto, constituem testemunho científico. Todavia, discordamos de Fuster Ruiz quanto à imparcialidade do documento de arquivo.

Para justificar nossa última colocação, recorremos às palavras de Cook (1998) que questionou conceitos tradicionais da Arquivística e abordou alguns pensamentos dos "pósmodernos" a respeito dos métodos arquivísticos. Segundo Cook, para os pós-modernos, o contexto por trás dos textos, as relações de poder que conformam a herança documental dizem

InCID: R. Ci. Inf. e Doc., Ribeirão Preto, v. 2, n. 2, p. 42-53, jul./dez. 2011. 
tanto respeito quanto o próprio assunto, que é o conteúdo do texto. Para o autor, nada é neutro e imparcial, portanto, tudo é conformado, apresentado, representado, simbolizado e significado por aqueles que falam, fotografam e/ou escrevem com um propósito definido. Assim, conclui que nenhum texto é um mero subproduto e sim um produto consciente para criar ou servir a um propósito, embora essa consciência - esse contexto por trás do texto possa ser transformado, perdido, ou deturpado em padrões inconscientes de comportamento social, em um discurso institucional e em fórmulas padronizadas de apresentação.

Para Trace (2002), os cientistas da informação, desde a década de 1990, começaram a levar em consideração a importância de conhecer e reconhecer a natureza dos objetos por ele manipulados. Dessa forma, demonstra a importância de tratar os documentos e sua preservação não só como prova de uma ação, mas como elementos construídos socialmente e, por isso, representantes, desde a sua origem, dos interesses das instituições que os produzem, utilizam, preservam ou disponibilizam para consulta.

Agora, para definirmos qual tipo de informação é objeto para a Ciência da Informação e a historicidade deste termo, precisamos realizar um estudo mais detalhado. Para tanto, recorreremos às considerações de Bravo (2002), que propõe quatro linhas de tratamento para este termo: informação objetiva, informação subjetiva, informação como matéria e informação como processo. Para finalizarmos, trabalharemos as análises de Buckland (1991) sobre informação-como-coisa, informação-como-processo e informação-como-conhecimento - ponto de partida de nossas considerações.

Como colocado por Bravo (2002), em fins da década de 1970, alguns teóricos como Sannon e Weaver, atrelados às teorias matemáticas e racionalistas, tentavam desenvolver análises no sentido de encontrar um conceito de informação formalizado, matemático, que pudesse ser medido e expressado por unidades físicas. Neste pensamento, a informação seria algo por si só, autônoma, natural e independente do universo do receptor. Assim, a objetividade proposta pela informação e seu status superior a qualquer forma de intervenção a afastaria, por completo, de todo aspecto semântico; possível mediante os significados atribuídos pelo receptor. Sob esta questão, Pérez Gutiérrez diz que nesta concepção a informação é vista como elemento que precede o receptor e, por isso, este não deve ser considerado.

No mesmo período, final da década de 1970 e início de 1980, outra linha de pensamento estruturava-se e compreendia a informação a partir da sua subjetividade. Os trabalhos de Belkin, Wilson, Dervin e Brookes, trataram questões mais voltadas ao ponto de vista que privilegiava o enfoque cognitivo da informação. Neste ponto, a informação é um 
acontecimento que tem lugar em uma etapa concreta do processo de comunicação. Ou seja, a informação seria um termo adequado para um acontecimento que acorre dentro da mente humana como absorção de uma mensagem, isto é, informação é um acontecimento efetivo, que produz um efeito. Nesta linha, da informação subjetiva, encontramos que para existência da informação é necessário que haja um emissor e um receptor. Enquanto a idéia de informação objetiva tendia a encarar o emissor como inocente, a linha da informação subjetiva pressupunha que ele não é inocente e tem uma intenção ao produzir uma informação. Portanto, esta aproximação subjetiva considerava tanto o emissor quanto o receptor e a informação como algo situacional (circunstancial), inevitável e variável em função do receptor e seu estado de conhecimento (Bravo, 2002).

Um terceiro pensamento estava vinculado a algumas das versões propostas por Buckland e Machlup. A Internacional Standard Organization (ISO), na obra Recueil de documentation et Information (ISO, 1998), apresentou duas definições para o conceito de informação: a informação como algo que se comunica e a informação como uma mensagem utilizada para representar um texto, com o fim de incrementar o conhecimento. Nesta linha, considerava-se tanto a informação subjetiva quanto a objetiva, uma vez que compreendia que a primeira é construída no pensamento dos receptores, entendida e localizada em um contexto específico de tempo-espaço. Já a informação objetiva, seria uma entidade externa, que chega a ser um objeto autônomo, cujo fluido não é controlado nem pelo produtor, nem pelo receptor. A informação objetiva estaria, portanto, além do contexto de tempo-espaço. Ainda nesta linha de pensamento, considerava-se que a informação existe através de um processo em que diferentes indivíduos criam diferentes imagens ou idéias (informação subjetiva), a partir das mesmas informações externas (informação objetiva) (Bravo, 2002).

A quarta proposta do entendimento do conceito de informação é aquela que considera a informação como um ente material, como informação registrada em um suporte. Por meio desta corrente, nos embasaremos nas colocações de Buckland (1991), sobre informaçãocomo-coisa.

Este autor avaliou o termo informação a partir de seus usos e apresentou-o por meio de três fases funcionais, denominadas: informação-como-processo, informação-comoconhecimento e informação-como-coisa.

Segundo Buckland (1991), a informação-como-processo seria o ato de informar e comunicar algo a alguém. Já a informação-como-conhecimento, seria aquilo apreendido, pelo receptor, na etapa referente à informação-como-processo, ou seja, no processo de aquisição da informação. No entanto, tais explicações para o conceito de informação, são apresentadas 
como intangíveis, pois podem gerar apenas conhecimentos tácitos, que dificilmente podem ser percebidos, manipulados ou recuperados por sistemas de informação. Por esta questão, Buckland ao lançar o termo informação-como-coisa, pretendeu trabalhar a informação física, tangível, e possível de ser tratada por sistemas de informação. Este termo seria, portanto, aplicado a coisas informativas (objeto, dado, evento), desde que tivessem a qualidade de conhecimento comunicado, materializado. Para o autor, diversas coisas podem ser consideradas informativas dependendo das circunstâncias, ou seja, a informação seria algo situacional.

Para Capurro e Hjorland (2007, p. 192), esta "análise de Buckland parece ter duas conseqüências importantes: por um lado, introduz o conceito de documento (informaçãocomo-coisa) e, por outro, indica a natureza subjetiva da informação". Os autores também analisam que Buckland, ao considerar que qualquer coisa pode ser simbólica, sustenta a idéia de que qualquer coisa pode ser informativa/informação.

Para Hjorland (2000), Buckland analisou importantes aspectos na história da documentação. Segundo o autor, no século XX os documentalistas derrubaram a ideia de que existia uma necessidade para o termo genérico, uma expressão para os objetos cobertos pela atividade da documentação, na medida em que incluíra não somente textos, mas também objetos naturais, artefatos, trabalhos feitos para representar ideias e objetos de arte. Assim, mostra que o conceito 'documento' (ou unidade da documentação) passou a ser visto por Buckland como uma ferramenta, um meio para ensinar e informar algum assunto, desde que este fosse comunicado.

Como visto, percebemos que diversas áreas como o Direito, a Historiografia e basicamente a Documentação estão olhando recentemente o documento como objeto central e, sob a luz das preocupações da Cultura Material, vêm percebendo que ele não é somente uma conseqüência natural de uma determinada função, e, portanto, uma prova no tempo; mas, pelo contrário, que o documento também é um agente que pode influenciar, senão, determinar as vidas das pessoas ou suas relações sociais.

Schwartz e Cook (2002, p. 5) mostram que historiadores, antropólogos, teóricos culturais, sociólogos e outros estudiosos têm descoberto e focalizado o contexto da produção documental e que isto tem sido essencial para reconsiderar a relação entre arquivos e as sociedades que os criam e usam, pois no coração desta relação está o poder: de registrar certas coisas em detrimento de outras; de privilegiar ou marginalizar; sobre direitos individuais e liberdades; sobre memórias e identidades nacionais. Desta forma, os registros se aproximam do poder na medida em que são os meios pelos quais certas vozes são ouvidas para que outras

InCID: R. Ci. Inf. e Doc., Ribeirão Preto, v. 2, n. 2, p. 42-53, jul./dez. 2011. 
sejam silenciadas; para que certas visões e ideias sobre a sociedade sejam privilegiadas e outras marginalizadas. Segundo os autores, é necessário olharmos novamente para o arquivo levando em conta as mudanças na produção e preservação de documentos. Outro foco estabelecido é o da relevância de se considerar a natureza do que é documentado, assim como o criador do documento.

Frohmann (2008) considera que nos últimos anos tem sido dada maior atenção à importância da documentação em várias disciplinas nas ciências sociais, com o intuito de mostrar como a documentação trabalha para construir e trazer entidades à luz e manter a sua permanência. Para ele, os estudos de documentação têm operado ao longo de dois eixos: o documento - a coisa - e a documentação - o processo. Ao analisar os trabalhos de Michel Callon, mostrou-os como grande contribuição para ontologia documentária na medida em que revela mais sobre o que os documentos fazem e sobre os processos de documentação do que sobre as características específicas das coisas que nós podemos chamar de documentos. Frohmann, assim, convida-nos a olhar o rastro que os documentos e a documentação deixam, como eles funcionam, como fazem as coisas existirem e como têm o poder de manter esta existência.

Dessa forma, conforme foi discutido ao longo do texto percebemos que novos olhares emergem sobre a maneira de entender o documento não unicamente como um dispositivo social, mas também como um fenômeno conceitual. A emergência de uma preocupação específica com o documento, aparece com a Historiografia. Notadamente com a corrente positivista do século XIX, para a qual não existia veracidade do "dizer o passado", se não estivesse respaldada pela simples existência do documento. Posteriormente, essa validação do documento, passa por uma revisão até chegar no consenso de que o caráter verídico do documento está fora dele, naquilo que alguns chamam de contexto e que nos propomos a chamar de institucionalização.

A Arquivologia aderiu a visão positivista mencionada, jogando no documento de arquivo três tipos de valores: administrativo, histórico e de informação. Os três valores, sempre embasados nessa veracidade escondida no simples ser do documento. Sem perceber que, paradoxalmente é o respaldo institucional do arquivo e simplesmente ele, e não o documento, que faz "dizer a verdade".

Essa percepção última procede das novas interpretações do documento. Essas percepções, em primeiro lugar, destacam a materialidade da informação, isto é a sua fixação, permanência e inscrição num suporte e formato físico. O que faz o documento manipulável, organizável e estável. E, num segundo lugar, essa materialidade permite sua inserção, uso e 
circulação social. Isto é, permite que se tornem campo de ação e de expressão dos diferentes interesses, tensões e enfrentamentos dos grupos que se interpenetram dentro ou tangencialmente no documento.

Portanto, o pensamento sobre o documento, obedece a uma historicidade na qual, pelos seus agenciamentos, ele se constitui num fenômeno social. Configurando também, por outro lado, as preocupações específicas sobre ele. Nascido dentro de determinado marco que o configura, suas características serão essas e não outras justamente pelas suas atribuições históricas.

\section{REFERÊNCIAS}

BELLOTTO, Heloísa Liberalli. Arquivos permanentes: tratamento documental. São Paulo: T. A. Queiroz, 1991.

BLOCH, Marc. Apologia da história ou o ofício de historiador. Rio de Janeiro: Jorge Zahar, 2002.

BRAVO, Blanca Rodríguez. EI documento: entre la tradición y la renovación. Ediciones Trea, 2002.

BUCKLAND, Michel K. Information as thing. Journal of the American Society for Information Science (JASIS), v. 45, n. 5, p. 351-360, 1991.

CAPURRO, Rafael; HJORLAND, Birger. O conceito de Informação. Perspectivas em Ciência da Informação, Belo Horizonte, v. 12, n. 1, p. 148-207, jan./abr. 2007.

COOK, Terry. Arquivos pessoais e arquivos institucionais: para um entendimento arquivístico comum da formação da memória em um mundo pós-moderno. Estudos Históricos, Rio de Janeiro, v. 11, n. 21, p. 129-149, 1998.

COUTURE, Carol. Le concept de document d'archive à láube du troisième millénaire. Archives, v. 27, n. 4, 1996.

FOUCAULT, Michel. Microfísica do poder. Rio de Janeiro: Graal, 1979.

FROHMANN, Bernd. The role of facts in Paul Otlet's modernist project of documentation. In: RAYWARD, W. Boyd. European modernism and the information society: informing the present, understanding the past. Aldershot, Hants, England; Burlington, VT: Ashgate, 2007. 2008.

Documentary ethics, ontology, and politics. Archival Science, v. 3, n. 8, p. 165-180,

FUSTER RUIZ, Francisco. Archivística, archivo, documento de archivo. . . necessidad de clarificar los conceptos. Anales de Documentación, n. 2, p. 103-120, 1999. 
HJORLAND, Birger. Memory, institutions and information science. Journal of Documentation, v. 56, n. 1, p. 27-41, jan. 2000.

LE GOFF, Jacques. História e memória. Campinas: Ed. Unicamp, 2003.

SCHWARTZ, Joan M.; COOK, Terry. Archives, records, and power: the Making of modern memory. Archival Science, v. 2, p. 1-19, 2002.

SENÉCAL, Sylvian. La lecture et la description archivistique du document. Arquives, v. 29, n. 3 e 4, 1997-1998.

TALLAFIGO, Manuel Romero. Archivísyica y archivos: soportes, edificio y organización. Carmona: S\&C, 1997.

TRACE, Ciaran B. What is recorded is never simply "What Happened": record keeping in modern organizational culture. Archival Science, v. 2, p. 137-159, 2002. 